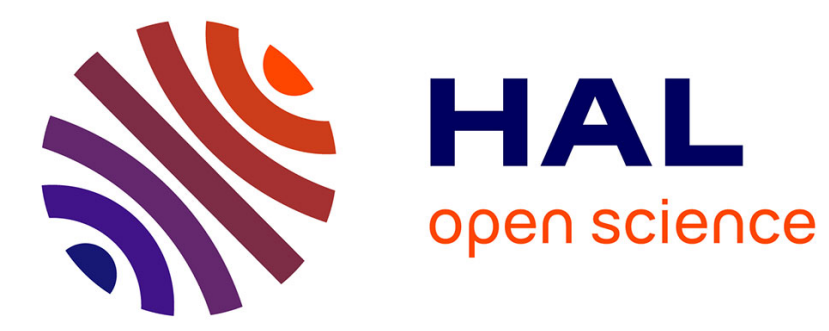

\title{
Circuit-based synthesis of a reflectarray
}

Alexandre Grossetete, Erwan Fourn, Raphaël Gillard, Maria Garcia-Vigueras

\section{To cite this version:}

Alexandre Grossetete, Erwan Fourn, Raphaël Gillard, Maria Garcia-Vigueras. Circuit-based synthesis of a reflectarray. IEEE International Symposium on Antennas and Propagation, Jul 2017, San Diego, United States. hal-01724170

\section{HAL Id: hal-01724170 https://hal.science/hal-01724170}

Submitted on 6 Mar 2018

HAL is a multi-disciplinary open access archive for the deposit and dissemination of scientific research documents, whether they are published or not. The documents may come from teaching and research institutions in France or abroad, or from public or private research centers.
L'archive ouverte pluridisciplinaire HAL, est destinée au dépôt et à la diffusion de documents scientifiques de niveau recherche, publiés ou non, émanant des établissements d'enseignement et de recherche français ou étrangers, des laboratoires publics ou privés. 


\title{
Circuit-based synthesis of a reflectarray
}

\author{
Alexandre Grossetete, Erwan Fourn, Raphael Gillard, Maria Garcia-Vigueras \\ Institut of Electronics and Telecommunications of Rennes (IETR) \\ Rennes, France \\ alexandre.grossetete@insa-rennes.fr \\ maria.garcia-vigueras@insa-rennes.fr
}

\begin{abstract}
This paper presents a new methodology for synthesizing reflector panel based on a fully analytical model. The present methodology is applied to the simple case of a two levels reflector panel consisting of metallic strips unit-cell. The model generates a maximal error of $3.39^{\circ}$ on the reflection phase.
\end{abstract}

\section{INTRODUCTION}

The synthesis of a reflectarray consists in controlling the reflected phase on each unit cell to generate the desired phase law. For passive arrays, this is achieved by fixing the geometrical dimensions of each unit-cell [1].

The current methods used to design reflectarrays are mostly based on full-wave analysis. Databases with the electromagnetic parameters of a large number of unit-cell geometres are computed using full-wave simulations and then used to synthesize the given reflectarray. However these methods are time consuming especially for precise databases and complex cells.

The objective of this work is to provide a quick sizing method for all cells in order to reduce calculation time. The proposed solution consists in designing each unit-cell by using its associated equivalent circuit. This method has been recently used in designing reflectarrays antenna [2] based on the equivalent circuit model proposed in [3].

In this paper, we propose a fully analytical synthesis methodology based on a $\mathrm{n}$ efficient and physically insightful circuit model [4]. This new approach is applied to the canonic case of a planar reflector composed of metallic strips.

\section{EQUiVALENT CIRCUIT BASIS}

Fig. 1(a) presents the structure of the reflector unit-cell under consideration of $P_{x} \times P_{y}=6 \times 6 \mathrm{~mm}^{2}$. The pattern considered is a metallic strip of width $w$. The unit-cell consists of two dielectric slabs of thickness and dielectric permittivity $h_{1}=598 \mu \mathrm{m}, \epsilon_{r_{1}}=3.55$ and $h_{2}=7.9 \mathrm{~mm}, \epsilon_{r_{2}}=1$ respectively. The unit cell is illuminated under normal incidence by a TE ( $E_{y}$ field component) polarized impinging wave.

The equivalent circuit of the unit-cell is shown in Fig. 1(b). The strip is modeled by an inductance $L_{1}$. Both dielectric slabs are represented by two transmission lines of lengths $h_{(1,2)}$, characteristic impedances $Z_{c_{(1,2)}}$ and propagation constants $\beta_{(1,2)}$.

Equation 11 expresses the form of the admittance $Y_{L_{1}}^{M o d e l}$ of the inductance $L_{1}$ as a function of the width $w$ and the frequency of operation $f_{0}$. As detailed in [4], $A_{n}^{q s}$ represents the amount of energy coupled to each of the infinite highorder harmonics $n$ supported by the periodic structure. $Z_{i n, n}^{q s}$ expresses the input impedance seen by each high-order harmonics.
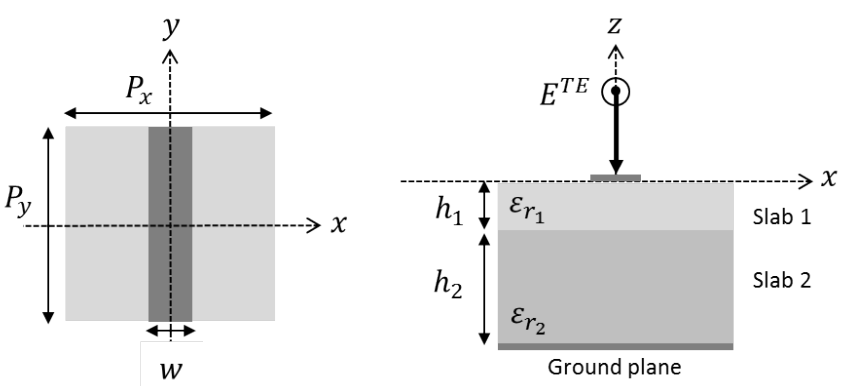

(a)

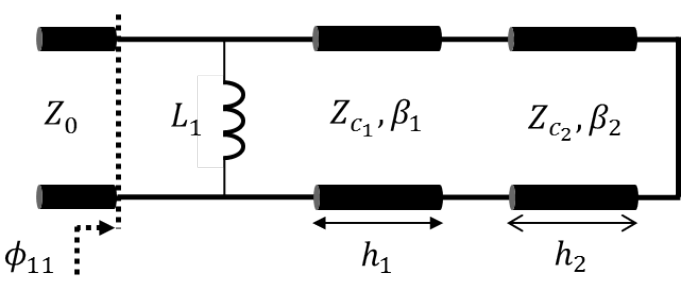

(b)

Fig. 1. (a) Unit cell. Top view (left). Cross-section view (right). (b) Associated equivalent circuit.

$$
Y_{L_{1}}^{M o d e l}\left(f_{0}, w\right)=2 \sum_{n=1}^{\infty} A_{n}^{q s}(w) Z_{i n, n}^{q s}\left(f_{0}\right)
$$

\section{SYNTHESIS OF THE REFLECTOR}

\section{A. Structure of the reflector}

Note that, for the sake of simplicity, the structure is supposed to be illuminated by a plane wave under normal incidence. Then, we will call it a reflector instead of reflectarray. We only consider steering in the $x 0 z$-plane, which means the cells along one $y$-column are all identical and form a continuous strip. Fig. 2 presents the structure of the proposed reflector. This canonical case has the advantage to validate the proposed synthesis methodology. The structure consists of two panels shifted along the $z$-axis. Indeed, as the pattern is purely inductive and according to the arrangement of the dielectric slabs considered, the phase range available at $f_{0}=12.5 \mathrm{GHz}$ 
is only of $180^{\circ}$. In order to increase the phase range, a solution consists in putting a second panel shifted of $h_{0}=\lambda_{0} / 4$ from the reference plan. A complete phase range of $360^{\circ}$ is then obtained.

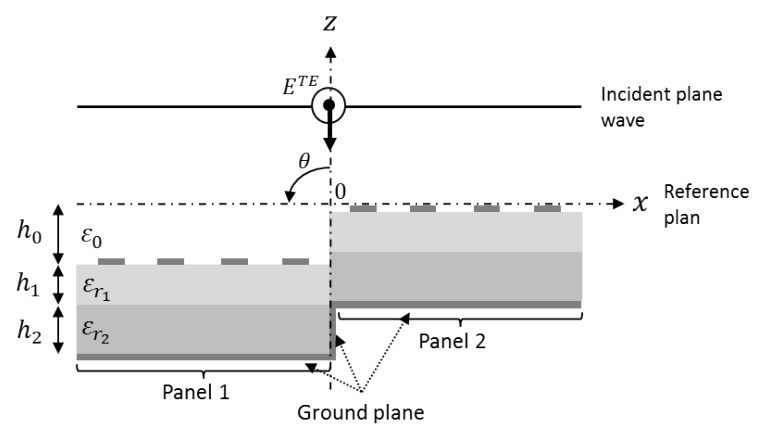

Fig. 2. Design of the reflector.

\section{B. Synthesis of the reflector}

The specifications on the radiation pattern are the following. The maximum of the main beam has to appear at an angle of $\theta=-10^{\circ}$ with a half-power beamwidth (HPBW) of $10^{\circ}$ at $f_{0}=12.5 \mathrm{GHz}$. In order to do this, a linear phase step of $15.62^{\circ}$ has to be apply on the 20 cells of the reflector ( 10 cells per panel). The first panel has to cover a phase range from $-156.27^{\circ}$ to $-15.62^{\circ}$ and the second one from $0^{\circ}$ to $140.65^{\circ}$.

These phase specifications are then converted into an admittance specifications on $Y_{L_{1}}^{\text {Spec }}$ (cf. Fig. 3(a) . Each width $w$ is then deduced by equalizing the admittance $Y_{L_{1}}^{\text {Model }}$, using 11, with $Y_{L_{1}}^{\text {Spec }}$ (cf. Fig. 3(b)). The maximal error generated by the model on the reflection phase is $3.39^{\circ}$ (cf. Fig 3(c).

\section{RESUlts}

Fig 4 presents the normalized radiation pattern of the reflector simulated under HFSS ${ }^{\mathrm{TM}}$. The full-wave results are in good agreement with the specifications. Indeed, the main lobe presents a maximum at $\theta=-10^{\circ}$ with a HPBW of $10^{\circ}$.

\section{CONCLUSION}

This paper presents a full analytical synthesis methodology of a reflector. Our methodology has been applied to a conical case of a reflector consisted of two shifted panels. The results obtained from the full-wave simulation show a good agreement with the specifications and prove the efficiency (low time consuming) and the accuracy of the analytical model.

\section{REFERENCES}

[1] D. G. Berry, R. G. Malech, and W. A. Kennedy, "The reflectarray antenna," IEEE Trans. Antennas Propag., May 1963.

[2] S. M. A. M. H. Abadi, K. Ghaemi, and N. Behdad, "Ultrawideband, true-time-delay reflectarray antennas using ground-planebacked, miniaturized-element frequency selective surfaces," IEEE Trans. Antennas Propag., vol. 63, no. 2, February 2015.

[3] O. Luukkonen, C. Simovski, G. Granet, G. Goussetis, D. Lioubtchenko, A. V. Räisänen, and S. A. Tretyakov, "Simple and accurate analytical model of planar grids and high-impedance surfaces comprising metal strips or patches," IEEE Trans. Antennas Propag., vol. 56, no. 6, 2008.

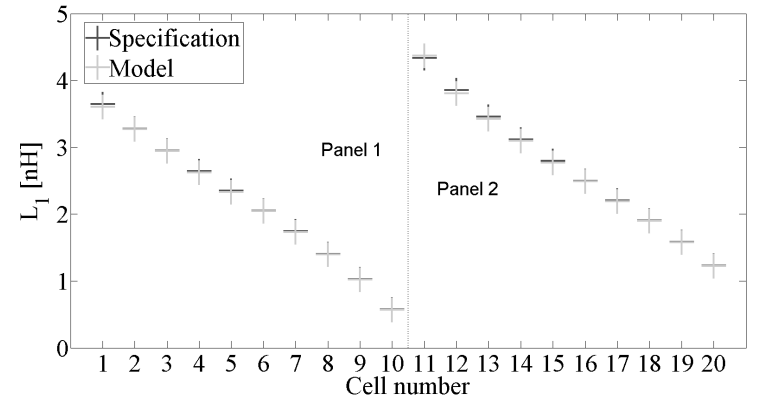

(a) Comparison between the specified inductance $L_{1}^{S p e c}$ (deduced from $Y_{L_{1}}^{S p e c}$ ) and the model inductance $L_{1}^{\text {Model }}$ (deduced from $Y_{L_{1}}^{\text {Model }}$ ) for each unit-cell.

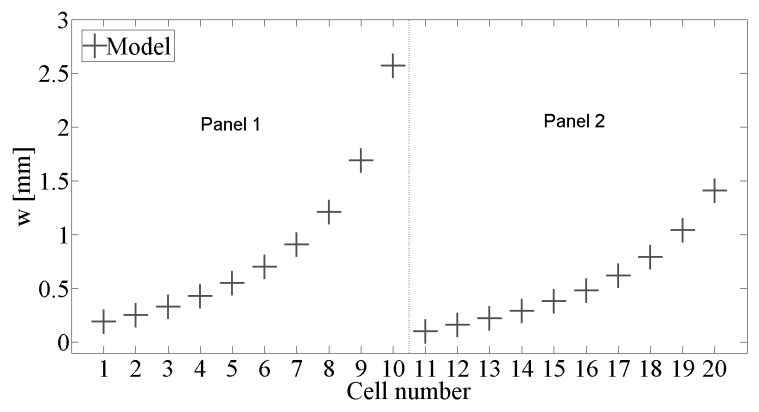

(b) Deduction of the values of the width $w$ on each unit-cell.

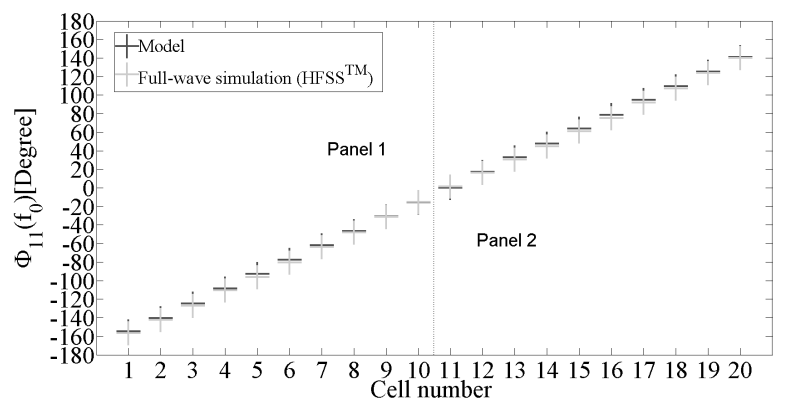

(c) Accuracy of the analytical model on the reflection phase on each unit-cell.

Fig. 3. Synthesis of the reflector.

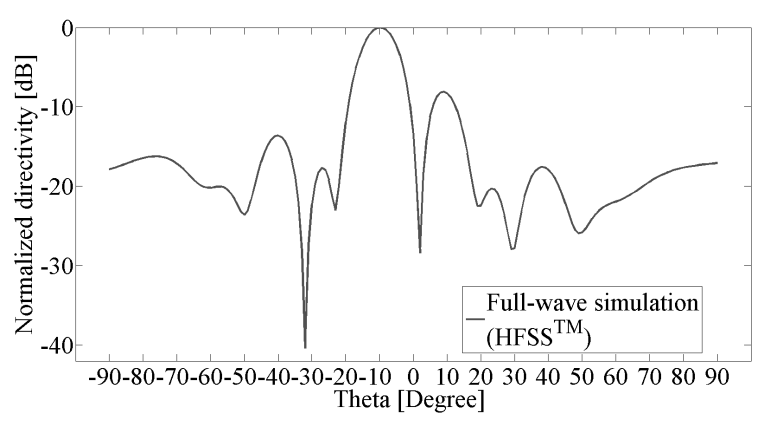

Fig. 4. Simulated radiation pattern in the plan $x 0 z$.

[4] R. Rodriguez-Berral, C. Molero, F. Medina, and F. Mesa, "Analytical wideband model for strip/slit gratings loaded with dielectric slabs," IEEE Trans. Antennas Propag., vol. 60, no. 16, December 2012. 